\title{
Employability Skills of Business Graduates in Job Markets of Bangladesh: Investigating Weaknesses and Suggesting Improvements
}

\author{
Mohammad Milon', Mohammed Rafiqul Islam²*, and Md. Atiqur Rahman Khan ${ }^{1}$ \\ ${ }^{1}$ Department of Human Resource Management, Jatiya Kabi Kazi Nazrul Islam University, Mymensingh, Bangladesh; and \\ ${ }^{2}$ Department of Management, Jatiya Kabi Kazi Nazrul Islam University, Mymensingh, Bangladesh. \\ *Correspondence: rafiq.emu618@gmail.com (Mohammed Rafiqul Islam, Lecturer, Department of Management, Jatiya Kabi \\ Kazi Nazrul Islam University, Mymensingh, Bangladesh).
}

\begin{abstract}
Job seekers have to face intense competition to get the expected job in the current job market of Bangladesh. A plethora of job seekers especially business graduates are coming to the job markets having MBA degrees but fails or takes longer time to get expected jobs since employability skills are the prime requirement for every contemporary organization. The study aims to investigate the weaknesses in the employability skills of business graduates in Bangladesh and suggest some effective measures to curtail those weaknesses. A self-administered survey instrument developed, some items deleted after analysis, and some items revised to get a concrete one. This questionnaire sent to 300 students who already graduated with an MBA degree and are trying to get expected jobs. Among them, 280 usable responses collected and used as the sample in this study. The ranking method and proportion analysis used for analyzing the collected data. The findings revealed that the business graduates of Bangladesh possessed significant lacking employability skills as inadequate team-working skills, lack of communication and interpersonal skills, unable to learn and adapt to the environment, lack of negotiation skills, and shortage of organizing skills. Moreover, this study suggested some measures like providing proper training, arranging case competitions and job fairs, the mitigating gap between the schooling system and market demands, re-arranging the business curriculum, and so on for taking consideration by concerned authorities to solve the identified weaknesses.
\end{abstract}

Keywords: Employability skills, Business graduates, Professional knowledge, and University-industry linkage.

\section{INTRODUCTION:}

The employability skills are key requirements from the job seekers as if the activities of the organizations smoothly and successfully performed. At present, the job fields of Bangladesh are inadequate, challenging, and much more competitive. In this connection, many business graduates can not avail jobs immediately after completing their graduation due to lacking of different employability skills such as communication skills,
English language proficiency and literacy, information and technology skills, interpersonal skills, leadership skills, problem solving skills, adaptability skills, risk taking skills, etc. In the words of Stewart and Knowles, (2000), the major ardor of business graduates is not only to study a selective course in depth, but also to enhance their employability skills. Therefore, there is a greater need for business graduates to enhance their employability skills. Employability skills defined as 
basic skills necessary for getting, keeping and doing well in a job across all industries (Singh and Singh, 2008).

Those are not required only for entering into a job but also for ensuring personal and organizational progress. Employability skills can contribute to take strategic decisions successfully. It is logically focus on graduates' abilities to adapt and use their personal and academic skills to create more tangible educational outcomes that assure employment (Akter, 2020). It is one kind enthusiasm of outgoing students to contribute in employment in terms of talents, abilities, attitude, and understanding (Mason et al., 2009). Subsequently, it is spontaneous capability of the students to be proficient in soft and hard skills (Ahmad et al., 2010), which could subsidize additional achievement in the job and triumph in their selected careers, which benefits themselves, the workforce, the society and the country (Yorke and Knight, 2006).

The graduates should be adaptable and flexible in organization to acquire current understandings so that they would be able to make changes as essential by the environment at that time (Saad et al., 2013). Thus, we can say that a situation in which fresh graduates can prove themselves worthy to the organization by acquiring skills, knowledge and attitude in their relevant field is called employability skill. Lately, most of the reputed organizations in our country choice personnel who can confirm the proprietorship of employability skills to perform jobs. Organizations are always give emphasize on graduate's possession on some skills such as analytical ability, problem solving skills, critical thinking capability, strategy formulation, quantitative analysis and so on. Proficiency in technology and modern research methods can add extra value, which can enhance their confidence and effectiveness.

Moreover, the managers also add that the business graduates should have some other academic and occupational capabilities such as practical case solving ability, the ability to give practical examples for the underlings, the ability to have industry network and affiliation, business management expertise, demonstration and communication skills, worldwide business understanding, etc.

UniversePG I www.universepg.com
The matter of regret that, most of the business graduates fail to get expected jobs or to influence the probable organizations due to the lacking in their employability skills and these are common concern for both the employers and job candidates. Outgoing graduates are not proactive enough to identify the exact demands of potential employers due to they cannot maintain a continuous involvement with the corporate world. Lack of vocational, practical and need-based education is also responsible for deficiency in employability skills. Furthermore, companies want that business graduates must well prepared with appropriate practical skills with some soft skills like innovation and creativity, entrepreneurial spirit, leadership, critical thinking skills so that they can enter easily to the job market after completing graduation. Many researchers investigated this issue very carefully to find out reasons behind the incompetence of our education system. Based on this situation, this study has conducted to investigate some pivotal skills shortcomings of our business graduates and suggest some effective measures for minimizing those weaknesses.

\section{Review of the Related Literature}

Employability is a difficult concept to measure and define (Harvey, 2001; Pegg et al., 2012; Sewell \& Dacre Pool, 2010). Employability concept appears to grow in line with the changes in work pattern and workforce model. McQuaid and Linda, (2005) stated that current labor market policy has been determined by considering employability of the potential candidates although in the past days it was a totally ambiguous and imprecise concept. At present, it considered as the most important criteria to formulate policies and strategies for the labor market. After completing graduation, a graduate can play a vital role in the society and economy. As they will be able to ensure high salary and income, they have considered as social elites in many regions.

Nevertheless, a disparity exists among the graduates as to their labor market outcomes facing the problem of no working experience, lower CGPA grades, unsuitable field of specialization, lack of technical skills, no career goal and knowledge of job, negative personality traits etc. Employability skills (skills that employers want) means foundational academic, personal and 
teamwork skills, communication skills, critical thinking skills, analytical ability and problem solving skills, using one's initiative and being self-motivated, working under pressure and to deadliness, organizational skills, ability to learn and adapt, numeracy, valuing diversity and difference, negotiation skills etc. that employers expect from workers for a job. These knowledge, skills and abilities are required for receiving, possessing, and undertaking perfectly on the own employment.

In the words of Sherer and Eadie, (1987), employability skills such as oral and written communication, the ability to work in team and interpersonal skills, that are foundational to both academic and workplace success. According to Dearing, (1997), the capacity of a fresh graduate to get work suitable to his educational qualification called employability skill. Besides, Buck and Barrick, (1987) stated that employability skills are attributes of employees, other than technical competence, that make the man asset to an employer. Similarly, Yorke and Knight, (2004) defined employability skills as a set of attainment that encompasses abilities, skills, knowledge, and personal qualifications which can make a person unique and qualified to perform achieving organizational goals and objectives. A good supply of skilled employable graduates in job is essential for national, economic and social well being and the failure to equip young people with employability skills has far-reaching consequences. Moreover, Dearing, (1997) insisted that the present business graduates should possess oral communication, language proficiency, quantitative analysis, problem solving, creative and innovative thinking, learning skills, decision making, dependability, optimistic approach to responsibility, team player, punctuality, selfconfidence, self-efficacy, adaptability or flexibility, etc.

Similarly, Williams and Cranmer, (2006) indicated employability skills mean work readiness. Work readiness is a state of individual who possesses the knowledge, skills and aptitude that can help him/her to make dynamic assistances to achieve organizational goals and objectives. Mason, Baxter and Young, (1982) have also specified that companies want entry-level employees who are responsible and reliable, technologically proficient, communicative and have the wish UniversePG I www.universepg.com to absorb and progress the capability to perform in team, and hold a right approach.

A report published by the Asian Development Bank, (2014) states that graduates must master employability skills, also called foundation training, and proficiencies in order to find meaningful work in which foundation skills are basic skills, thinking abilities, and personal potentials and competencies include resource, interpersonal, information, systems, and technology competencies. In this case, Roshid and Chowdhury, (2013) argue that today's young graduates need to continuously update existing knowledge and proficiency and obtain new skills and qualifications as a result of the rapidly changing economy and labor market. Hillage and Pollard, (1999) identified three important factors that can ensure employability of a candidate. Those factors are ability to get opening job, ability to continue this job, and ability to find out and get new job if required. According to Cox and King, (2006), educational institutions have come under intense pressure to equip graduates with more than just the academic skills. Employers request universities and educational institutions through issuing reports and statistics regarding labor market to develop the basic and convertible skills, which typically needed in the almost all types of job. Consequently, it is essential for educational institutions to have a working affiliation with corporate sector to fulfill the demands and specifications of the organizations. Nevertheless, in today's thought-provoking business atmosphere the control of only subject knowledge alone is no longer enough for fresh graduates in fulfilling company requirements; gradually it needed for them to advance moveable abilities, which will boost op their predictions of work (Cox and King, 2006; Fallows and Stevan, 2000; Harvey et al., 1997; Warn and Tranter, 2001).

According to Mitchell (2006), to be successful in this dynamic, progressively competitive business situation, companies must claim personnel with capabilities, which will show the path to a great yield on the worker investment. In this case, university can do the task of curriculum revisions, organizing industry-related lecture series, organizing workshops and training program with the help of corporate affiliation, industry placement, and mock interviews/tests organizing university industry counseling session. On the other 
hand, employers can do the task of sponsoring training after hiring, hosting employer events in universities, participating in university industry consultative session. In this context, Hegarty and Johnston, (2008) propose that the educational institutions should ensure corporate involvement in designing course curriculum, conducting courses, and requisite to reveal the courses of study fulfill with requirements for professional and legal bodies, level descriptors, and academic review. Graduates can up skill themselves by using portfolios of personal improvements (Stephens \& Hamblin, 2006; Brine \& Feather, 2003). Currently, institution of advanced education produces their thought on the matter of employability among young graduates where they are unable to protect their jobs once they graduated. The main issue behind this problem is the absence of employability skills among graduates, which below average from the employer's demand. Sincerely, graduate believes that they earned essential skills, abilities and knowledge to fulfill their firm's expectancy in executing their jobs and advance their careers once they finish their study in university (Rosenberg et al., 2011; Bok, 2006). However, not all graduates' employability meets the employer's expectation and this result to unemployment among graduates (Rashid and Islam, 2020).

\section{Objectives of the research}

The main rationale of this study is to identify the key problems in the employability skills of business graduates required by the organizations. For this purpose, the study also focuses:

- To show the business graduate's expected job fields in Bangladesh;

- To provide some relevant suggestions to overcome the weaknesses in their employability skills.

\section{METHODOLOGY:}

Research Design - This study designed entirely to analyze the research questions to find out the result indicated by the research objective in the context of Bangladesh. Both the quantitative and qualitative data used for getting the result of this research.

Sampling and Data Collection - The researchers used the convenient sampling method to determine the sample size from the population and to reach the sample. The researchers selected the students having graduation and post-graduation degree from different universities of Bangladesh, staying in the Dhaka city and are currently seeking jobs in different organizations as the sample area.

A well-structured questionnaire containing the items related to the employability skills sent to 300 business graduates who were searching their expected jobs. Among them, 280 usable responses collected and used as sample in this study. Five point Likert Scale (strongly agree-strongly disagree) was used for the questions. Then, the collected data analyzed by using descriptive statistics as well as ranking method based on percentage of respondents. Statistical Package for Social Science (SPSS) used to complete the analysis and relevant interpretation.

\section{Limitations of the Study}

The following limitations have considered in the time of conducing this research.

- Firstly, there were some limited respondents to their sample size and composition.

- Secondly, some respondents were unsupported to complete the questionnaires.

- Thirdly, since the data collection task confined at Dhaka city only, it may fail to represent the pervasive result for widely used.

\section{RESULTS AND ANALYSIS:}

In this research, the final data has collected from 280 respondents of various universitie's MBA students by using a structured survey questionnaire. All the questionnaires have personally administered to each respondent and the response rate was satisfactory. The collected data have analyzed by using simple statistics and results tabulated and reported in parentages.

Demographic Profile of the Respondents - The questionnaires section have been assisted us to understand about respondent's profile focusing on respondent's gender, age, material status and professional status, etc. Total number of respondents is 280 and among them male is 180 and female is 100 . 
Table 1: Demographic characteristics of the respondents

\begin{tabular}{|c|c|c|c|}
\hline & Particulars & Frequency & Percentage \\
\hline Gender & Male & 180 & 64.28 \\
& Female & 100 & 35.71 \\
\hline Age & $20-25$ & 120 & 42.85 \\
& $25-30$ & 90 & 32.14 \\
& $30-35$ & 70 & 25.00 \\
\hline Marital & Single & 265 & 94.6 \\
Status & Married & 15 & 5.4 \\
\hline \multicolumn{2}{|c|}{ No. of respondents = 280 } \\
\hline
\end{tabular}

According to Table 1, the 180 of respondents are male and 100 of respondents are female. In the time of age consideration, 42.85 percent of the respondents were between 20 and 25 , between 25 and 30, the percentage was 32.14 and 25.00 percent of respondents were between 30 and 35 ages. Moreover, single was 94.6 percent while married was 5.4 percent.

Respondents' desired job fields - In line with the questionnaire survey and literature review, the following respondents' desired job fields have found (Table 2). From the above table, most of the business graduates' desired job fields are Bank (28.57\%) and Multinational companies (21.42\%) where many graduates are reluctant to develop career in government job. In addition to, teaching profession (8.92\%) was the great interest for some selected respondents.
Table 2: Respondents' desired job fields

\begin{tabular}{|c|c|c|}
\hline $\begin{array}{c}\text { Types of respondents' } \\
\text { desired job fields }\end{array}$ & Frequency & Percentage \\
\hline Banking Jobs & 80 & 28.57 \\
\hline Academic Profession & 25 & 08.92 \\
\hline Bangladesh Civil Service & 50 & 17.85 \\
\hline $\begin{array}{c}\text { Public Service Commission } \\
\text { (PSC)/Govt. jobs }\end{array}$ & 30 & 10.71 \\
\hline $\begin{array}{c}\text { Multi-national companies } \\
\text { Job (MNCs) }\end{array}$ & 60 & 21.42 \\
\hline $\begin{array}{c}\text { Local Leading Company } \\
\text { Telecommunication sectors }\end{array}$ & 20 & 07.14 \\
\hline $\begin{array}{c}\text { Ready-Made Garments } \\
\text { (RMGs) }\end{array}$ & 05 & 03.57 \\
\hline Total & 280 & $100 \%$ \\
\hline
\end{tabular}

Weaknesses of Required Employability Skills of the Business Graduates - We have identified several employability problems in the review of literature. Lack of highly qualified professional attitude, shortage of specialized knowledge in different business areas, lack of link between industry and academia, lack of specialized training, lack of good quality research, lack of corporate leadership attitude, no adjustment with performance evaluation system, lack of orientation and socialization, lack of knowledge about impressive management are remarkable.

Table 3: Weaknesses of Required Employability Skills of the Business Graduates

\begin{tabular}{|c|l|c|c|c|}
\hline S. N. & \multicolumn{1}{|c|}{ Weaknesses in Employability Skills } & Frequency & Percentage & Ranks \\
\hline 01. & Poor communication and interpersonal skills & 38 & 13.57 & 02 \\
\hline 02. & Lack of problem solving skills & 25 & 08.92 & 06 \\
\hline 03. & Using your initiative and being self-motivated & 20 & 07.14 & 09 \\
\hline 04. & Less attitude of working under pressure and to deadlines & 22 & 07.85 & 08 \\
\hline 05. & Lack of organizing skills & 32 & 11.42 & 05 \\
\hline 06. & Absent of team working skills & 42 & 15.00 & 01 \\
\hline 07. & Less ability to learn and adapt the environment & 36 & 12.85 & 03 \\
\hline 08. & Inadequate Numeracy & 07 & 02.50 & 10 \\
\hline 09. & Valuing diversity and difference & 23 & 08.21 & 07 \\
\hline 10. & Lack of negotiation skills & 35 & 12.50 & 04 \\
\hline & $\mathbf{2 8 0}$ & $\mathbf{1 0 0 \%}$ & \\
\hline
\end{tabular}

From the analysis of the above Table 3 it is observed that, on the basis of the questionnaire survey, total 10 employability skills have been identified by the respondents and all the skills are ranked based their frequ- ency and percentage for finding the most important skills among them. The highest percentage indicates the highest important value among the above 10 skills. So the major skills by their percentage and rank are 
Team working skills (15\%); Communication and Interpersonal Skills (13.57\%); Ability to learn and adapt $(12.85 \%)$; Negotiation Skills (12.50\%); Organizational Skills (11.42\%); Problem Solving Skills (08.92\%); Valuing Diversity and Difference (08.21\%);
Working under pressure and to deadlines (07.85\%); Using your initiative and being self-motivated $(07.85 \%)$; Numeracy $(02.50 \%)$. The above percentages shown in the following pie chart:

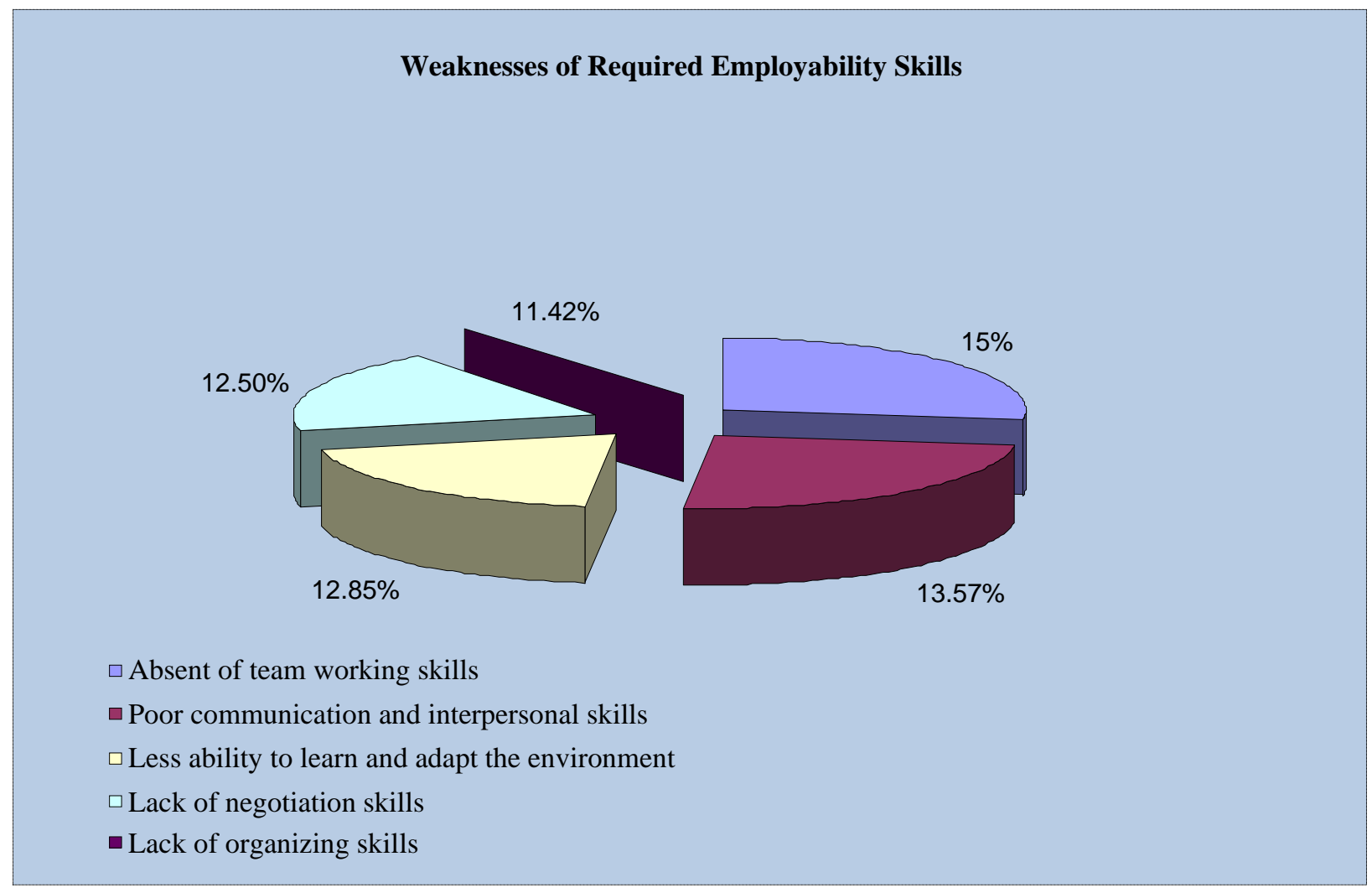

Fig 1: Weaknesses of required employability skills of the business graduates.

The above pie chart illustrates 05 major weaknesses of employability skills extracted from the above percenttage distribution table (Table 3). The five major skills are (i) Absent of team working skills (15\%); (ii) Poor communication and interpersonal skills (13.57\%); (iii) Less ability to learn and adapt the environment (12. $85 \%$ ); (iv) Lack of negotiation skills (12.50\%); (v) Lack of organizing skills (11.42\%).

\section{Suggestions for Improvement}

From the literature review and respondents' data analysis, it is clear that graduates are still challenging some crucial employability skills that are required to overcome as fast as possible for getting some better jobs. The business graduates can concentrate to the following guidelines -

- They can emphasis on teamwork skills such as corporate leadership, up-to-date case based study and executive training. They can also assure to acquire in-depth knowledge of some specific topic, being specialization and English language proficiency.

- The graduates can ensure communication and interpersonal skills being adequate qualified professional attitude employees and business researchers, etc.

- They should keep the skills about ability to learn and adapt for making a linkage between academia and industry to achieve specialized training in different fields.

- They should keep Negotiation Skills in their dayto-day organizational task to follow a good performance evaluation system, effective learning materials, appropriate and well-designed course curriculum, reliable and standard examination system. 
- The business graduates should consider organizational skills for being skillful and productive employees with effective administrative sup-port and leadership, adequate investment as well as de-politicization of learning environment.

\section{CONCLUSION:}

Since Business graduates are pivotal part of our today's professional education, employability skills are the best source of preparing managers and executives for the future. An immense proliferation of business graduates throughout the world has become the milestone of enhancement its quality and application in our country. In this regard, our business graduates should keep a touch of $21^{\text {st }}$ century's employability skills such as Communication, Teamwork, Problem solving, Initiative and enterprise, Planning and organizing, Self-management, Learning, Technology. In addition to business graduates can be initiated by some concerned skills such as corporate knowledge, better communication skill, up-to-date case based study and executive training; in-depth knowledge, field of specialization and English language proficiency; adequate business research; university and industry linkage; training and professional development, etc.

Besides, graduates should be adjusted with proper reward and appraisal system, in addition to, the business graduates can be improved by making a strong linkage between universities and industry, receiving training from the resource person, allocating proper budget to research, and ensuring effective mechanism for teachers' evaluation and compensation etc. Last but not the least, a complete and harmonious effort would take by both the govern-ment and private owners to minimize the current business graduates' employability skills problems in our country.

\section{ACKNOWLEDGEMENT:}

Gratitude to all the authors whose books and articles have cited. Besides, many thanks to all who have supported to do this research.

\section{CONFLICTS OF INTEREST:}

Authors declare no conflicts of interest to publish it.

\section{REFERENCES:}

1) Ahmad, S., Ishak, N.M., Ismail, K. \& Selamat, J. (2010). Generic Competency Profile among Students in Institute of Higher Learning: A Case of Universiti Kebangsaan Malaysia (UKM), Malaysia, College Student Journal, 44(3), pp. 811-820. https://eric.ed.gov/?id=EJ917253

2) Akter S. (2020). Women employment opportunity on SMEs sector: Bangladesh perspective, Int. J. Manag. Account. 2(5), 105-118. https://doi.org/10.34104/ijma.020.01050118

3) Asian Development Bank, (ADB), (2014). 'Asian Development Bank Annual Report'. Retrieved from https://www.adb.org/sites/default/files/institutio nal-document/158032/adb-annual-report-2014. pdf

4) Asif, (2015). 'Graduates Mismatch with Job Market Demand.' Retrieved from http://archive.dhakatribune.com/business/2015/a pr/21/graduates-mismatch-job-market-demand

5) Bangladesh Labour Market Profile, (2020). Retrieved from -

https://www.ulandssekretariatet.dk/wp-content/ uploads/2020/07/LMP-Bangladesh-2020-Finalrev.pdf

6) Buck, L. \& Barrick, R. K. (1987). 'They are trained but are they employable?' Vocational Education Journal, 62(5), pp. 29-41. https://eric.ed.gov/?id=EJ355193

7) Cox, S. \& King D. (2006). 'Skills sets: An approach to embed employability in course design.' Journal of Education and Training, 48(4), pp. 262-274. https://doi.org/10.1108/00400910610671933

8) Dearing, R. \& Garrick, S. R. (1997). 'Higher education in the learning society.' The Committee. National Committee of Inquiry into Higher Education (Great Britain).

http://www.educationengland.org.uk/documents/ dearing1997/dearing1997.html

9) Harvey, L. (2000). 'New realities: The relationship between higher education and employment.' Tertiary Education and Management, 6(1), pp. 3-17. https://doi.org/10.1080/13583883.2000.9967007 
10) Harvey, L. \& Bowes, L. (1998). 'The impact of work experience on the employability of graduates'. Birmingham: University of Central England.

11) Hillage, J. and Pollard, E. (1998). 'Employability: developing a framework for policy analysis.' Department for Education and Employment, London. Retrieved from -

http://www.dfes.gov.uk/research/data/upload/\% EF\%AC\%81les/RB85.doc

12) Ismail, N. A. (2011). 'Graduates' characteristics and unemployment: A study among Malaysian graduates.' International journal of business and social science, 2(16), pp. 94-102. https://ijbssnet.com/journals/Vol_2_No_16_Sept ember 2011/11.pdf

13) Knight, P. \& Yorke, M. (2004). 'Learning, Curriculum and Employability in Higher Education.' Routledge Falmer, London.

14) Mason, G., Williams, G. \& Cranmer, S. (2009). 'Employability Skills Initiatives in Higher Education: What Effects do they have on graduate labour market outcomes?' Education Economics, 17(1), pp. 1-30. https://doi.org/10.1080/09645290802028315

15) Rashid MH and Islam MA. (2020). Impacts of unemployment on graduates in Bangladesh: a case study, Br. J. Arts Humanit., 2(5), 87-94. https://doi.org/10.34104/bjah.020087094

16) Rosenberg, S., Heimler, R., \& Morote, E. S. (2011). 'Basic Employability skills: a traingular design approach.' Journal Education and Training. 54(1), pp. 7-20.

https://doi.org/10.1108/00400911211198869

17) Roshid, M., M. \& Chowdhury, R. (2013). 'English language proficiency and employ- ment: A case study of Bangladeshi graduates in Australian employment market.' Mevlana International Journal of Education (MIJE), 3(1), pp. 68-81. https://eric.ed.gov/?id=ED543591

18) Saad, M. S. M., Robani, A., Jano, Z. and Majid, I. A. (2013). Employers' perception on engineering, information and communication technology (ICT) students' employability skills, Global Journal of Engineering Education, 15(1), pp. 42-46.

https://d1wqtxts1xzle7.cloudfront.net/54095884/ WIETE-Employability_Skills.pdf?1502267449

19) Sherer, M. \& Eadie, R. (1987). 'Employability skills: key to success.' Thrust, 17(2), pp. 1617.

20) Singh, G. K. G. \& Singh, S. K. G. (2008). 'Malaysian graduates' employability skills.' UNITAR e-Journal, 4(1), pp. 15-45.

https://d1wqtxts1xzle7.cloudfront.net/24834985/ gurvindermalaysiangraduate 1.pdf

21) Stephens, D. \& Hamblin, Y. (2006). 'Employability Skills: are UK LIM departments meeting employment needs? The results of a survey of employment agencies identifies gaps in UK LIM curricula in the UK.' New Library World, 107(5), pp. 218-227. https://doi.org/10.1108/03074800610665211

22) Yorke, M. \& Knight, P. (2006). 'Embedding employability into the curriculum.' York: Higher Education Academy, 3. http://hdl.voced.edu.au/10707/185821

23) Yorke, M. and Knight, P. (2002). 'Skills Plus: Tuning the undergraduate curriculum. Skills plus project report.' Teaching in Higher Education, 8(1), pp. 3-16.

Citation: Milon M, Islam MR, and Khan MAR. (2021). Employability skills of business graduates in job markets of Bangladesh: investigating weaknesses and suggesting improvements, Int. J. Manag. Account. 3(1), 20-27. https://doi.org/10.34104/ijma.021.020027 @) 